\title{
Characterization and Biological Activity of Some New Derivatives Derived from Sulfamethoxazole Compound
}

\author{
Sanaa A. Alsahib \\ Received 4/4/2019, Accepted 2/12/2019, Published 1/6/2020

(⿶)

\begin{abstract}
:
A new series of Sulfamethoxazole derivatives was prepared and examined for antifibrinolytic and antimicrobial activities. Sulfamethoxazole derivatives bear heterocyclic moieties such as 1,3,4-thiadiazine $\{3\}$, pyrazolidine-3,5-diol $\{4\}$ 6-hydroxy-1,3,4-thiadiazinane-2-thione $\{5\}$ and [(3-methyl-5-oxo-4,5dihydro-1H-pyrazol-4-yl)diazenyl] $\{8\}$. Their structures were elucidated by spectral methods (FT-IR, $\mathrm{H}^{1}$ NMR). Physical properties are also determined for all compound derivatives. Recently prepared compounds were tested for their antimicrobial activity in the laboratory. Each screened compound showed good tendency to moderate antimicrobial activity.
\end{abstract}

Key words: Biological activity, Characterization, Sulfamethoxazole, Synthesis.

\section{Introduction:}

Sulfamethoxazole (SMZ or SMX) IUPAC is chemically labeled as 4-Amino $-\mathrm{N}-(5-$ methylisoxazol-3-yl) - benzenesulfonamide is a wide board antibiotic. It was approved in the United States in 1961. At present, it is mostly used in combination with trimethoprim (abbreviated SMXTMP). It is also referred to as sulfamethalazole, sulfisomezole, and sulfamethazole. It is used for many bacterial diseases and is effective against both germs positive and negative. (1) In the recent years, a great number of sulfamethoxazole derivatives were synthesized, characterized, tested and used for the treatment of many infections. (2)A large number of Sulfamethoxazole derivatives are currently designed based on heterocyclic moieties, they are widely used in clinical medicine exhibits as pharmacological agents with a wide range of biological procedures such as anti-cancer treatment, (3)antiviral agents, (4)anti-fungal, (5)herbicidal activities, (6) antimycobacterial (7) and antitubercular uses (8). In the light of the facts and due to the huge development in antimicrobial activities of sulfamethoxazole derivatives, a series of heterocyclic rings such as 1,3,4-thiadiazine, pyrazolidine-3,5-diol, 6-hydroxy-1,3,4thiadiazinane-2-thione compounds are designed and synthesized.

Department of Chemistry, College of Science for Woman, University of Baghdad, Baghdad, Iraq.

E-mail: sanaa_abdul@yahoo.com

*ORCID ID: https://orcid.org/0000-0002-3527-5464
The chemical structure of Sulfamethoxazole is 4-Amino $\quad-N$-(5-methylisoxazol-3-yl) benzenesulfonamide.

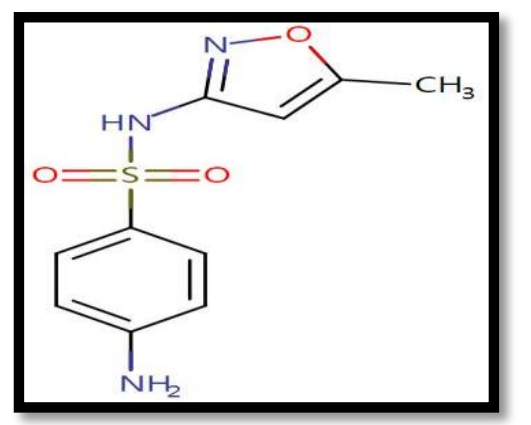

Figure 1. Structure of Sulfamethoxazole (1)

\section{Materials and Methodologies:}

All the chemicals used in this work were of highest purity available and supplied without further purification in Layer Chromatography (TLC) was checked by pro-coated sheets with silica -gel as immobile phase Appropriate solvent(ethanol) as mobile phase (Melting points) was specified by Stuart melting point SMP10 Spectr (FT-IR) were via $\mathrm{KBr}$ disk on SHIMADZU FT-IR-8300 spectrophotometer in Ibn Sina Company and College of Sciences for Women in University of Baghdad. ${ }^{1} \mathrm{H}-\mathrm{NMR}$ measurements were achieved from Moscow University of Russia, operated at $500 \mathrm{MH}_{\mathrm{Z}}$ in DMSO-d 6 . 
Synthesis methods 2- chloro- N- [ 4- (2chloroacetamido) phenyl)sulfonyl) - N- (5methylisoxazol- 3- yl]acetamide compound (1) preparation (9)

To a stirred solvent of 4-amino- $N$ - (5methylisoxazol-3-yl) benzenesulfonamide $(3.27 \mathrm{~g}, 1$ mmol.) in $(20 \mathrm{ml})$ dimethyl formamide, a chloroacetyl chloride ( $3 \mathrm{ml}, 3 \mathrm{mmol}$.) were added drop by drop. The reaction carried out by refluxing the reaction mixture for $(6 \mathrm{hrs}$.). The resulting solid product then has been filtered, dried, and recrystallized from ethanol. compound as listed in Table (1).

Synthesis methods 2-hydrazineyl-N-[(4-(2hydrazineylacetamido)phenyl)sulfonyl)-N-(5methylisoxazol-3-yl] acetamide compound preparation (10)

A mixture of a 2-chloro-N-[(4-(2chloroacetamido)phenyl)sulfonyl)-N-(5-

methylisoxazol-3-yl] acetamide (1) (4.8g, $1 \mathrm{mmol}$.) and hydrazine hydrate $99 \%$ ( $2 \mathrm{ml}, 2 \mathrm{mmol}$ ) has been refluxed to (3hrs.). Resulting solids were collected, washed, and recrystallized from ethanol. compound as listed in Table (1).

Synthesis methods N-[5-methylisoxazol-3-yl)-N(2-(phenylamino)-4H-1,3,4-thiadiazin-6-yl)-4[(2) phenyl amino) -4H-1,3,4-thiadiazin-6yl]amino]benzenesulfonamide compound preparation (11)

To a solution of 2-hydrazineyl-N-((4-(2hydrazineylacetamido)phenyl)sulfonyl)-N-(5-

methylisoxazol-3-yl)acetamide compound (2) (3.54 $\mathrm{g}, 1 \mathrm{mmol})$ in absolute ethanol $(20 \mathrm{ml}) p$-chloro phenylisocyanate $(5.46 \mathrm{~g}, 2 \mathrm{mmol})$ has been added and refluxed for $4 \mathrm{hrs}$. and checked by TLC. The reaction was cooled and the soluble matter was filtered, dried ,and re-crystallized from ethanol. compound as listed in Table (1).

Synthesis methods 2-(3,5-dihydroxypyrazolidin1-yl)-N-[(4-(2-(3,5-dihydroxypyrazolidin-1yl)acetamide] phenyl)sulfonyl)-N-(5methylisoxazol-3-yl)acetamide compound preparation. (12)

Amixtureof2-hydrazineyl-N-[(4-(2hydrazineylacetamido)phenyl)sulfonyl)-N-(5methylisoxazol-3-yl] acetamide compound (2) (3.54 $\mathrm{g}, 1 \mathrm{mmol})$, ethylacetoacetate $(1 \mathrm{mmol})$ respectively and absolute ethanol $(15 \mathrm{ml})$ was mixed carefully, reflexed for ( $3 \mathrm{hrs}$.). The reaction mixture is then concentrated and cooled with crushed ice to form the solid product, which is eventually filtered and re-crystallized from ethanol. compound as listed in Table (1).
Synthesis methods N-(6-hydroxy-2-thioxo-1,3,4thiadiazinan-6-yl)-4-[(6-hydroxy-2-thioxo-1,3,4thiadiazinan-6-yl)amino]-N-(5-methylisoxazol-3yl)benzenesulfonamide compound preparation. (13)

To a stirred ethanolic solution of $\mathrm{KOH}$ (1.12 g, $2 \mathrm{mmol})$ in $(20 \mathrm{ml}), 2$-hydrazineyl-N-((4(2-hydrazineylacetamido)phenyl)sulfonyl)-N-(5methylisoxazol-3-yl)acetamide compound (2) (3.54 g, $1 \mathrm{mmol})$, carbon disulfide $(2 \mathrm{ml}, 2 \mathrm{mmol})$ was added slowly and refluxed for (3hrs.). The solid precipitate was filtered, washed with ether, and dried and crystallized from ethanol. Compound as listed in Table (1).

Synthesis methods 4-(N-(5-methylisoxazol-3yl)sulfamoyl)benzene diazonium chloride compound (6) preparation. (14)

$(0.69 \mathrm{~g}, 1 \mathrm{mmol})$ Sodium nitrite is gently added to $(5 \mathrm{~mL})$ of concentrated hydrochloric acid at less than $5^{\circ} \mathrm{C}$. and then $(3.27 \mathrm{~g}, 1 \mathrm{mmol})$ of $4-$ amino-N-(5-methylisoxazol-3-yl)

benzenesulfonamide [sulfamethoxazole] it was slowly added to the solution over an hour. The reaction mixture was stirred for one more time for ( 2 hrs.).The reaction mixture was stirred for more time $\left(2\right.$ hrs. $\left.0-5 C^{0}\right)$. compound as listed in Table (1).

Synthesis methods Ethyl 2-[(4-(N-(5methylisoxazol-3-yl)sulfamoyl)phenyl)diazenyl]3-oxobutanoate compound (7) preparation. (15)

The clear solution of diazonium salt compound (6) (3g, $1 \mathrm{mmol}$. was added to solution of ethyl acetoacetate $(1.3 \mathrm{~g}, 1 \mathrm{mmol}$.) in sodium hydroxide $(0.4 \mathrm{~g} .1 \mathrm{mmol}$.$) . Mixture of reaction was$ refluxed for (3 hrs.). The solid product is filtered, washed with a little hot water, dried , and purified from ethanol. compound as listed in Table (1).

Synthesis methods 4-[(3-methyl-5-oxo-4,5dihydro-1H-pyrazol-4-yl)diazenyl]-N-(5-

methylisoxazol-3-yl) benzene sulfonamide compound (8) preparation. (16)

To $(3.9 \mathrm{~g}, \mathrm{mmol}$.) of ethyl $2-[(4-(\mathrm{N}-(5-$ methylisoxazol-3-yl)sulfamoyl]phenyl)diazenyl)-3oxobutanoate compound (7) hydrazine hydrate99\% (3.6g, $1 \mathrm{mmol}$.) gently added. The reaction mixture was reactivated for ( $3 \mathrm{hrs}$.) and then cooled to room temperature. The solid precipitate is formed washed, dried, and crystalized from ethanol. compound as listed in Table (1)

\section{Result and Discussion:}

Artificial pathways of newly prepared derivatives sulfamethoxazole are presented in Scheme (1) 


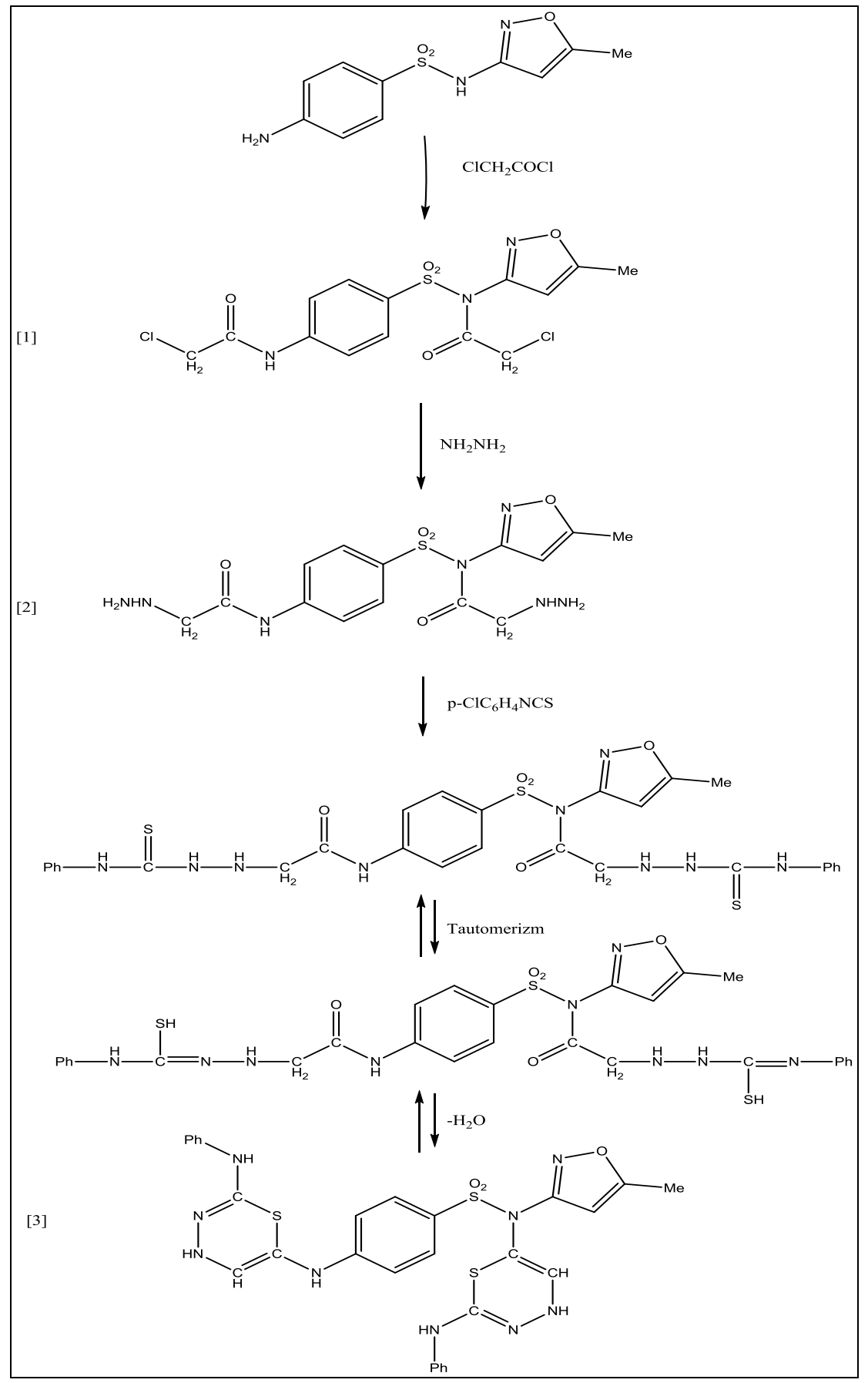

Scheme 1. Prepared derivatives sulfamethoxazole1,2,3-(9)

FTIR spectrum for compound(1) showed new band at $\left(3263 \mathrm{~cm}^{-1}\right)$ were assigned to the $\mathrm{v}(\mathrm{N}-$ $\mathrm{H})$ sym. stretching symmetry. Besides the appearances of $\mathrm{v}(\mathrm{C}=\mathrm{O})$ stretching band attributable to amide group at $\left(1693 \mathrm{~cm}^{-1}\right)$ and stretching band at $\left(2881 \mathrm{~cm}^{-1}\right)$ back to $\mathrm{v}\left(\mathrm{CH}_{2}\right)$ and at $\left(1600 \mathrm{~cm}^{-1}\right)$ for $(\mathrm{C}=\mathrm{N})$ isoxazole are best proof for the structure give to intended compound as listed in Table (2) FTIR spectrum of hydrazine carboxamide showed remarkable stretching bands in $\left(3321 \mathrm{~cm}^{-1}\right)$ and $\left(3267 \mathrm{~cm}^{-1}\right)$ which were assigned to the $v(-$
$\mathrm{NHNH}_{2}$ ) group frequency stretch proved the formation of compound (2). On the other hand, disappearance of $v\left(-\mathrm{NHNH}_{2}\right) \quad\left(\mathrm{CH}_{2}\right)$ and $(\mathrm{C}=\mathrm{O})$ group stretching frequency for thiadiazine ring is considered a good proof of formation of compound (3) FTIR spectrum for pyrazolidine-3,5-diol compound (4) gives starching bands for $\mathrm{v}(\mathrm{O}-\mathrm{H})$ at $\left(3365 \mathrm{~cm}^{-1}\right)$ and $\mathrm{v}\left(\mathrm{CH}_{2}\right)$ at $\left(2835 \mathrm{~cm}^{-1}\right)$. While pyrazolone compound (5) shows starching bands for $\mathrm{v}(\mathrm{C}=\mathrm{S}) 1165$ beside starching bands for $\mathrm{v}(\mathrm{O}-\mathrm{H})$ at $\left(3363 \mathrm{~cm}^{-1}\right)$ and $\mathrm{v}\left(\mathrm{CH}_{2}\right)$ at $\left(2835 \mathrm{~cm}^{-1}\right)$. 
Table 1. Physical properties of prepared compounds (1-8)

\begin{tabular}{cccccc}
\hline Compound no. & Mol. Formulas & Yield (\%) & m. p. ${ }^{\circ} \mathrm{C}$. & Color & Solv. Recryst. \\
\hline 1 & $\mathrm{C}_{14} \mathrm{H}_{13} \mathrm{Cl}_{2} \mathrm{~N}_{3} \mathrm{O}_{5} \mathrm{~S}$ & 65 & $184-186$ & Light yellow & Ethanol \\
2 & $\mathrm{C}_{14} \mathrm{H}_{19} \mathrm{~N}_{7} \mathrm{O}_{5} \mathrm{~S}$ & 77 & $118-120$ & Light brown & Ethanol \\
3 & $\mathrm{C}_{28} \mathrm{H}_{25} \mathrm{~N}_{9} \mathrm{O}_{3} \mathrm{~S}_{3}$ & 59 & $150-152$ & Light brown & Ethanol \\
4 & $\mathrm{C}_{20} \mathrm{H}_{27} \mathrm{~N}_{7} \mathrm{O}_{9} \mathrm{~S}$ & 88 & $166-168$ & Light brown & Ethanol \\
5 & $\mathrm{C}_{16} \mathrm{H}_{19} \mathrm{~N}_{7} \mathrm{O}_{5} \mathrm{~S}_{5}$ & 81 & $136-138$ & Deep brown & Ethanol \\
6 & $\mathrm{C}_{10} \mathrm{H}_{9} \mathrm{ClN}_{4} \mathrm{O}_{3} \mathrm{~S}$ & 66 & $144-146$ & yellow & Ethanol \\
7 & $\mathrm{C}_{16} \mathrm{H}_{18} \mathrm{~N}_{4} \mathrm{O}_{6} \mathrm{~S}$ & 70 & $170-172$ & Light orange & Ethanol \\
8 & $\mathrm{C}_{14} \mathrm{H}_{14} \mathrm{~N}_{6} \mathrm{O}_{4} \mathrm{~S}$ & 69 & $190-192$ & white & Ethanol \\
\hline
\end{tabular}

Table 2. FTIR v $\left(\mathrm{cm}^{-1}\right)$ spectral data for sulfamethoxazole compounds (1-8)

\begin{tabular}{|c|c|c|c|c|c|c|c|c|}
\hline $\begin{array}{c}\text { Compound } \\
\text { no. }\end{array}$ & $v(\mathrm{~N}-\mathrm{H})$ & $\begin{array}{c}v(\mathrm{C}-\mathrm{H}) \\
\text { Ar. }\end{array}$ & $\begin{array}{l}v(\mathrm{C}-\mathrm{H}) \\
\text { Aliph. }\end{array}$ & $\begin{array}{c}v(\mathrm{C}=\mathrm{N}) \\
\text { isoxazole }\end{array}$ & $\begin{array}{c}v(\mathrm{C}=\mathrm{C}) \\
\text { Ar. }\end{array}$ & $\begin{array}{l}v(\mathrm{SO} 2) \\
\text { Asym. }\end{array}$ & $\begin{array}{c}(\mathrm{SO} 2) \\
\text { sym. }\end{array}$ & Others \\
\hline 1 & 3263 & 3089 & 2951 & 1600 & 1554 & 1377 & 1180 & $\begin{array}{c}\left(\mathrm{CH}_{2}\right) 2881, \\
(\mathrm{C}=\mathrm{O}) 1693, \\
(\mathrm{C}-\mathrm{Cl}) 794 .\end{array}$ \\
\hline 2 & 3267 & 3059 & 2943 & 1597 & 1566 & 1334 & 1180 & $\begin{array}{l}\left(\mathrm{CH}_{2}\right) 2285, \\
(\mathrm{C}=\mathrm{O}) 1708 .\end{array}$ \\
\hline 3 & 3283 & 3071 & 2954 & 1600 & 1519 & 1377 & 1165 & $\begin{array}{c}(\mathrm{C}=\mathrm{N}) 1624 \\
\text { thiadiazine }\end{array}$ \\
\hline 4 & 3267 & 3093 & 2943 & 1604 & 1519 & 1334 & 1180 & $\begin{array}{l}(\mathrm{O}-\mathrm{H}) 3365, \\
\left(\mathrm{CH}_{2}\right) 2835 .\end{array}$ \\
\hline 5 & 3263 & 3089 & 2935 & 1604 & 1519 & 1334 & 1380 & $\begin{array}{l}(\mathrm{O}-\mathrm{H}) 3363, \\
\left(\mathrm{CH}_{2}\right) 2835, \\
(\mathrm{C}=\mathrm{S}) \mathrm{1} \text { ) }\end{array}$ \\
\hline 7 & 3267 & 3075 & 2970 & 1600 & 1519 & 1377 & 1161 & $\begin{array}{l}\left(\mathrm{CH}_{2}\right) 2877, \\
(\mathrm{C}=\mathrm{O}) 1670 .\end{array}$ \\
\hline 8 & 3417 & 3078 & 2939 & 1643 & 1551 & 1373 & 1165 & $(\mathrm{C}=\mathrm{O}) 1724$. \\
\hline
\end{tabular}

Other sulfamethoxazole derivatives attached with pyrazolidine-3,5-diol rings, 6hydroxy-1,3,4-thiadiazinane-2-thione moieties compounds (4) and (5) respectively were prepared by condensation of compound (2) with ethylacetoacetate in absolute ethanol to offered compounds (4). On the other hand, intensification of the compound (2) with carbon dioxide in the base medium of potassium hydroxide gives compound (5) as shown in the Scheme (2). 


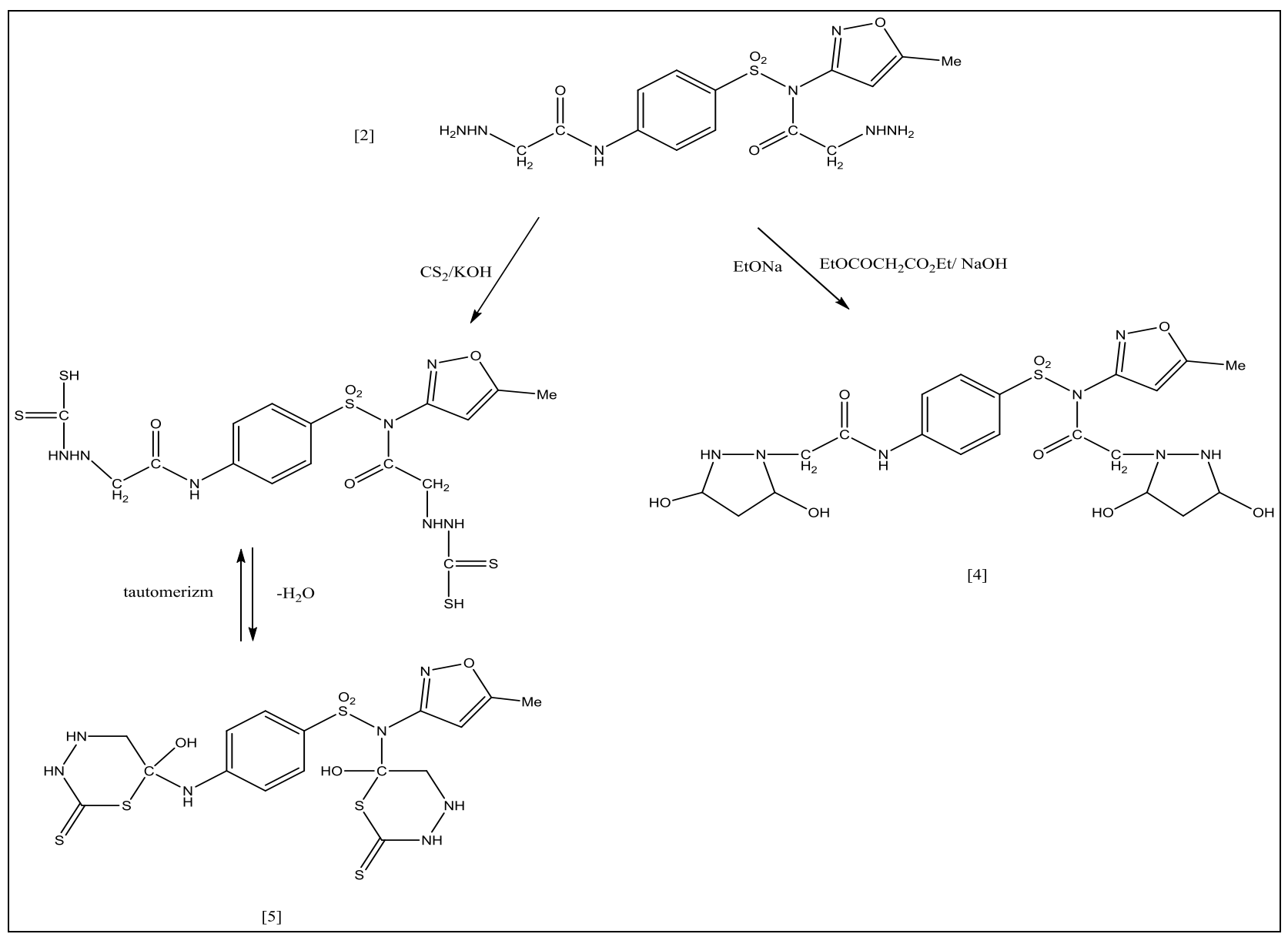

Scheme 2. Prepared derivatives sulfamethoxazole 4,5

${ }^{1} \mathrm{H}-\mathrm{NMR}$ spectrum of sulfamethoxazole compounds (1-3), shows the important characteristics of chemical shifts (DMSO- $\mathrm{d}_{6}, \mathrm{ppm}$ ) as listed in Table (3) .It displayed signals attributed to sulfamethoxazole attached to thiadiazine moiety compound (3), methyl group attached to isoxazole ring, for 2- $\mathrm{CH}$ - groups of thiadiazine ring, $(\mathrm{CH})$ isoxazole ring, fourteen aromatic ring protons, one proton of secondary amine $(\mathrm{NH})$, two protons of amines attached to phenyl group, two proton for amine group of thiadiazine respectively as shown in Table (3) ${ }^{1} \mathrm{H}-\mathrm{NMR}$ spectrum of pyrazolidine-3,5diol compound (4) displayed the basic characteristic signals(1.19) due to three protons of the methyl group connected to isoxazole ring, four protons of $\mathrm{CH}$ - pyrazolidine rings, four protons of methylene
$\mathrm{CO}-\mathrm{CH}_{2}-\mathrm{N}$, two protons of $\mathrm{NH}$ pyrazolidine, four protons metheylen pyrazolidine rings, one proton of $\mathrm{CH}$ isoxazole ring, four protns of hydroxyl groups $-\mathrm{OH}$, four protons of aromatic ring and one protone of $\mathrm{Ph}-\mathrm{NH}-\mathrm{CO}$ respectively as shown in Table-3.

${ }^{1} \mathrm{H}-\mathrm{NMR}$ spectrum of pyrazolone compound (5) detected significant characteristics of chemical shifts and showed suggested signals, the attribution of the $\left(\mathrm{CH}_{3}\right)$ linked to isoxazole ring, four protons for methylene groups of thiadiazinane rings, two protons of hydroxyl groups - $\mathrm{OH}$, one proton of $\mathrm{CH}$ isoxazole, four aromatic ring protons, four proton of $\mathrm{NH}$ thiadiazinane, and one proton of $\mathrm{Ph}$ $\underline{\mathrm{NH}}-\mathrm{C}$ thiadiazinane ring respectively as shown in the Table 3.(17) 
Table 3. ${ }^{1} \mathrm{H}$-NMR spectral data ( $\left.\delta \mathrm{ppm}\right)$ for selected prepared compounds

\begin{tabular}{|c|c|c|}
\hline Comp. No. & Compound structure & ${ }^{1} \mathrm{H}-\mathrm{NMR}$ parameters $(\delta \mathrm{ppm})$ \\
\hline 1 & & $\begin{array}{l}1.19\left(\mathrm{~s}, 3 \mathrm{H}, \mathrm{CH}_{3}\right), 4.67\left(\mathrm{~s}, 4 \mathrm{H}, \mathrm{CO}-\underline{\mathrm{CH}}_{2}-\mathrm{Cl}\right), 6.07(\mathrm{~s}, \\
\text { 1H, C-H), } \\
6.92-7.96(\mathrm{~m}, 4 \mathrm{H}, \mathrm{Ar}-\mathrm{H}), 12.39(\mathrm{~s}, 1 \mathrm{H}, \underline{\mathrm{NH}}-\mathrm{CO}) .\end{array}$ \\
\hline & & $\begin{array}{c}1.18\left(\mathrm{~s}, 3 \mathrm{H}, \mathrm{CH}_{3} \text { isoxazole }\right), 3.83\left(\mathrm{~s}, 4 \mathrm{H}, \mathrm{NH}_{2}\right), 4.65(\mathrm{~s}, \\
\left.2 \mathrm{H}, \mathrm{CO}-\mathrm{CH}_{2}-\mathrm{NH}\right), 4.96(\mathrm{~s}, 2 \mathrm{H}, \mathrm{NH}), 6.22(\mathrm{~s}, 1 \mathrm{H}, \mathrm{C}- \\
\mathrm{H}), 6.85-7.38(\mathrm{~m}, 4 \mathrm{H}, \mathrm{Ar}-\mathrm{H}), 12.22(\mathrm{~s}, 1 \mathrm{H}, \mathrm{NH}-\mathrm{CO}) .\end{array}$ \\
\hline 3 & & $\begin{array}{c}1.19\left(\mathrm{~s}, 3 \mathrm{H}, \mathrm{CH}_{3}\right), 4.67(\mathrm{~s}, 2 \mathrm{H}, \mathrm{C}-\mathrm{H} \text { thiadiazine }), 5.39 \\
(\mathrm{~s}, 1 \mathrm{H}, \mathrm{C}-\mathrm{H}), 6.92-7.93(\mathrm{~m}, 10 \mathrm{H}, \mathrm{Ar}-\mathrm{H}), 8.26(\mathrm{~s}, 2 \mathrm{H}, \\
\text { NH-Ph), 8.40(s, 1H, Ph-NH-C thiadiazine }), 8.88(\mathrm{~s}, 2 \mathrm{H} \\
\mathrm{NH} \text { thiadiazine }) .\end{array}$ \\
\hline 4 & & $\begin{array}{c}1.22\left(\mathrm{~s}, 3 \mathrm{H}, \mathrm{CH}_{3}\right), 1.87(\mathrm{t}, 4 \mathrm{H}, \mathrm{C}-\mathrm{H} \text { pyrazolidine }), 3.35 \\
\left(\mathrm{~s}, 4 \mathrm{H}, \mathrm{CO}-\mathrm{CH}_{2}-\mathrm{N}\right), 4.11(\mathrm{~s}, 2 \mathrm{H}, \mathrm{N}-\mathrm{H} \text { pyrazolidine }), \\
4.67\left(\mathrm{~s}, 4 \mathrm{H}, \mathrm{CH}_{2} \text { pyrazolidine }\right), \\
5.44(\mathrm{~s}, 1 \mathrm{H}, \mathrm{C}-\mathrm{H}), 5.81(\mathrm{~s}, 4 \mathrm{H}, \mathrm{OH}), 6.92-7.46(\mathrm{~m}, 4 \mathrm{H}, \\
\mathrm{Ar}-\mathrm{H}), 7.93(\mathrm{~s}, 1 \mathrm{H}, \mathrm{Ph}-\mathrm{NH}-\mathrm{CO}) .\end{array}$ \\
\hline 5 & & $\begin{array}{c}1.19\left(\mathrm{~s}, 3 \mathrm{H}, \mathrm{CH}_{3} \mathrm{i}\right. \\
4.67\left(\mathrm{~s}, 4 \mathrm{H}, \mathrm{CH}_{2} \text { thiadiazinane }\right), \\
5.52(\mathrm{~s}, 2 \mathrm{H}, \mathrm{OH}), 6.34(\mathrm{~s}, 1 \mathrm{H}, \mathrm{C}-\mathrm{H} \text { isoxazole }), 6.46- \\
7.83(\mathrm{~m}, 4 \mathrm{H}, \mathrm{Ar}-\mathrm{H}), 7.99(\mathrm{~s}, 4 \mathrm{H}, \mathrm{NH} \text { thiadiazinane }) \\
8.21(\mathrm{~s}, 1 \mathrm{H}, \mathrm{Ph}-\underline{\mathrm{NH}}-\mathrm{C} \text { thiadiazinane }) .\end{array}$ \\
\hline 7 & & $\begin{array}{c}1.62\left(\mathrm{~s}, 3 \mathrm{H}, \mathrm{CH}_{3}\right), \\
1.93\left(\mathrm{t}, 3 \mathrm{H}, \mathrm{CH}_{3} \text { isoxazole }\right), 3.52\left(\mathrm{q}, 2 \mathrm{H}, \mathrm{CH}_{2}\right), \\
4.30(\mathrm{~s}, 1 \mathrm{H}, \mathrm{C}-\mathrm{H}), 5.25(\mathrm{~s}, 1 \mathrm{H}, \mathrm{CH}), 6.96-7.97(\mathrm{~m}, 4 \mathrm{H}, \\
\mathrm{Ar}-\mathrm{H}), 9.32\left(\mathrm{~s}, 1 \mathrm{H}, \mathrm{SO}_{2}-\mathrm{NH}-\mathrm{C}\right),\end{array}$ \\
\hline 8 & & $\begin{array}{c}1.24\left(\mathrm{~s}, 3 \mathrm{H}, \mathrm{CH}_{3}\right), 1.88\left(\mathrm{~s}, 3 \mathrm{H}, \mathrm{CH}_{3} \text { pyrazole }\right), 2.08(\mathrm{~s}, \\
1 \mathrm{H}, \mathrm{CH}, \text { pyrazole }), 5.52(\mathrm{~s}, 1 \mathrm{H}, \mathrm{C}-\mathrm{H}), 6.92-7.65(\mathrm{~m}, \\
4 \mathrm{H}, \mathrm{Ar}-\mathrm{H}), 9.26\left(\mathrm{~s}, 1 \mathrm{H}, \mathrm{SO}_{2}-\mathrm{NH}-\mathrm{C}\right), 12.16(\mathrm{~s}, 1 \mathrm{H}, \mathrm{NH} \\
\text { pyrazole }) .\end{array}$ \\
\hline
\end{tabular}

Diazotization reaction of start sulfamethoxazole with sodium nitrite with hydrochloric acid yield the diazonium chloride derivative of sulfamethoxazole compound (6). Diazonium salt (4) then it was treated with ethyl acetoacetate in the presence of sodium hydroxide to give derivative (7). Final product of rings attached with sulfamethoxazole compound (8) were obtained in good yield from condensation of compound (7) with hydrazine hydrate. The synthetic routes for preparation of mentioned compounds (6-8) are shown in Scheme (3). 


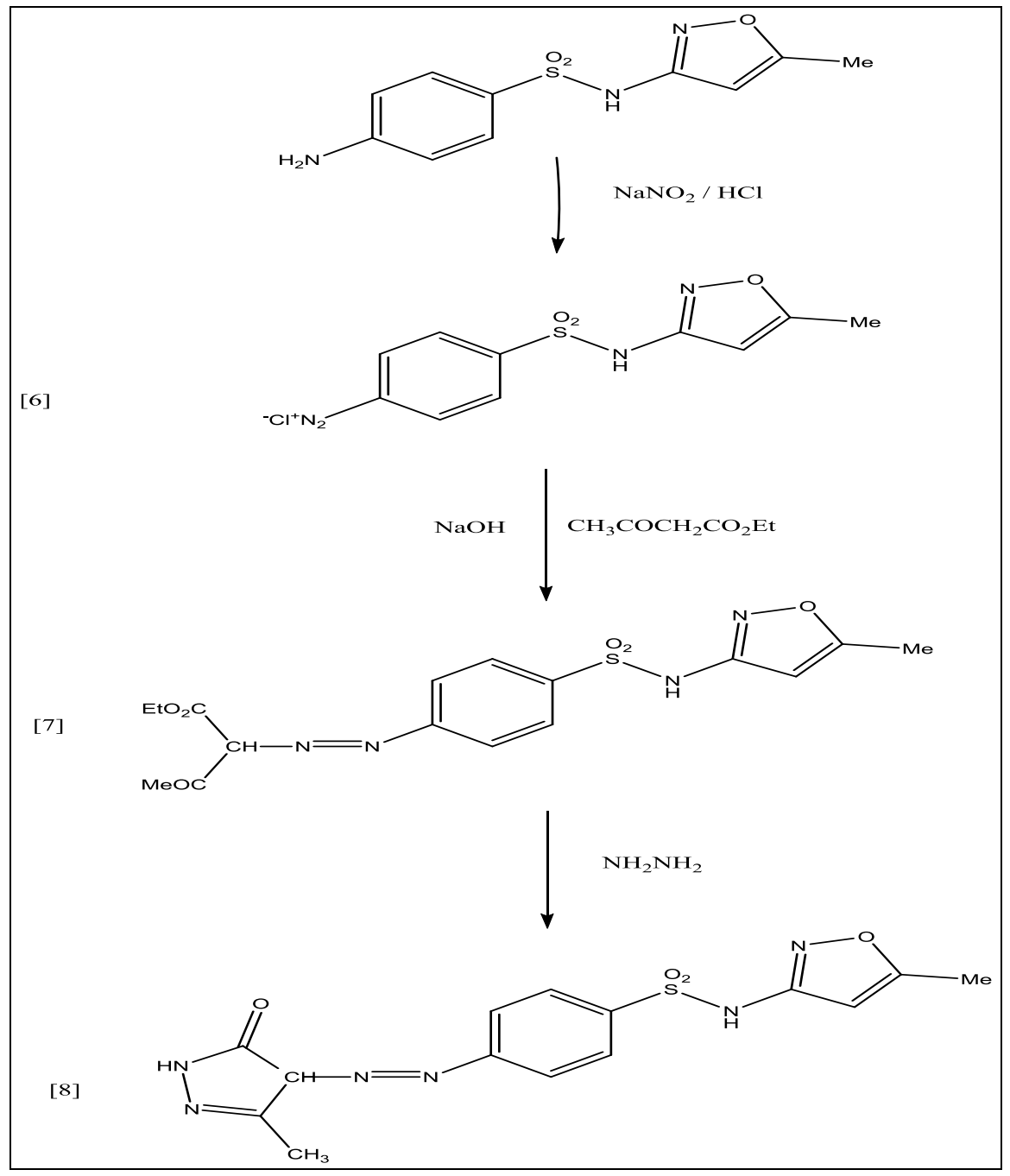

Scheme 3. Prepared derivatives sulfamethoxazole 6,7,8

FTIR spectrum for compounds (7) showed the characteristic starching band for $\mathrm{v}(\mathrm{N}-\mathrm{H})$ at $3267 \mathrm{~cm}^{-1}$ beside $\mathrm{v}\left(\mathrm{CH}_{2}\right)$ at $2877 \mathrm{~cm}^{-1}$ and ester group at $\left(1670 \mathrm{~cm}^{-1}\right)$. While pyrazole compound (8) showed starching band for $\mathrm{v}(\mathrm{N}-\mathrm{H})$ at $3217 \mathrm{~cm}-1$ beside $\mathrm{v}(\mathrm{C}=\mathrm{O})$ at $\left(1724 \mathrm{~cm}^{-1}\right)$.

${ }^{1} \mathrm{H}-\mathrm{NMR}$ spectrum of sulfamethoxazole derivatives (7 and 8), showed the characteristic chemical shifts (DMSO- $\mathrm{d}_{6}, \mathrm{ppm}$ ) as listed in Table (3).It displayed signals attributed for sulfamethoxazole linked to pyrazole moiety compound (8), $\mathrm{CH}_{3}$ isoxazole ring, pyrazole ring, one proton of $-\mathrm{CH}$ - pyrazole ring, one proton of $\mathrm{CH}$ - isoxazole ring, four aromatic ring protons, one proton of $\mathrm{SO}_{2}-\mathrm{NH}-\mathrm{C}$ and one proton of $\mathrm{NH}$ pyrazole ring respectively as shown in Table 3 .

\section{The Antimicrobial Activity:}

The inhibition zone of the newly synthesized sulfamethoxazole derivatives (1-5) were observed and measured. The biological activates of some prepared compounds $\left(\mathrm{C}_{1}, \mathrm{C}_{2}, \mathrm{C}_{3}\right.$, $\mathrm{C}_{4}, \mathrm{C}_{5}, \mathrm{C}_{6}$ ) were tested against bacterial strains and fungi. Escherichia coli, staphylococcus aureus and candida alb(1icans were well diffused using ager method. The results of this study are summarized in Table 4 and shown in Figs 1, 2 and 3 respectively.

Table 4. Biological measurements for some tested compounds

\begin{tabular}{ccccc}
\hline No. inhibition zone & Compound No.1000 ppm & E.coli & Staphylococcus aureus & Candida albicans \\
\hline $\mathrm{A}_{1}$ & $\mathrm{C} 1$ & $\mathrm{Nil}$ & 12 & Nil \\
$\mathrm{A}_{2}$ & $\mathrm{C}_{2}$ & Nil & 12 & 10 \\
$\mathrm{~A}_{3}$ & $\mathrm{C}_{3}$ & 10 & 14 & 20 \\
$\mathrm{~A}_{4}$ & $\mathrm{C}_{4}$ & 18 & 20 & 25 \\
$\mathrm{~A}_{5}$ & $\mathrm{C}_{5}$ & 10 & Nil & 10 \\
Control- $\left(\mathrm{A}_{6}\right)$ & 0 & 0 & 0 & 0 \\
\hline
\end{tabular}




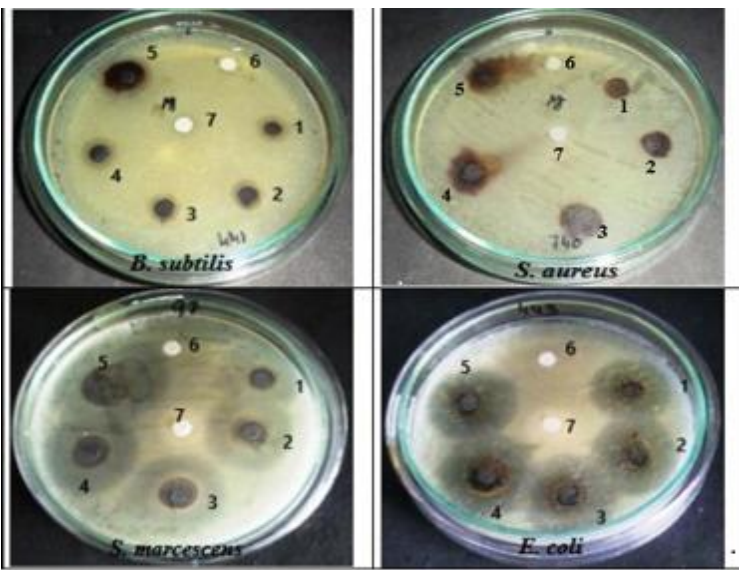

Figure 2. Action of prepared compounds on(E.coli)

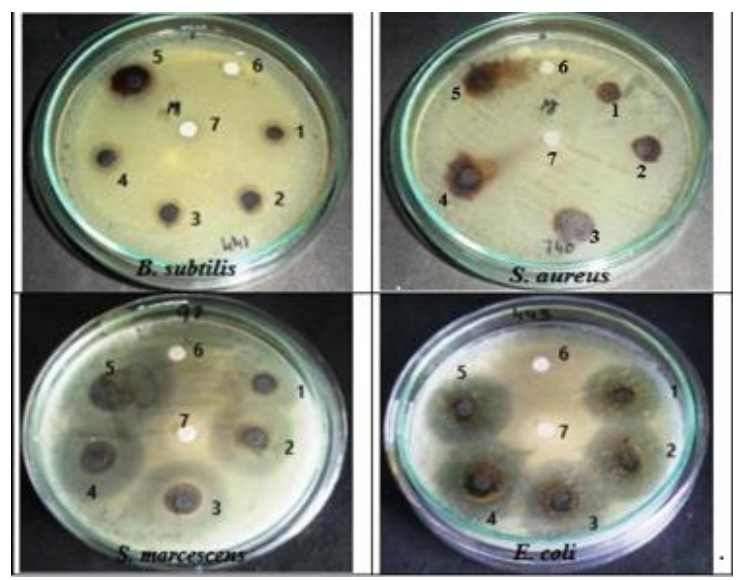

Figure 3. Action of prepared compounds on Staphylococcus aureus

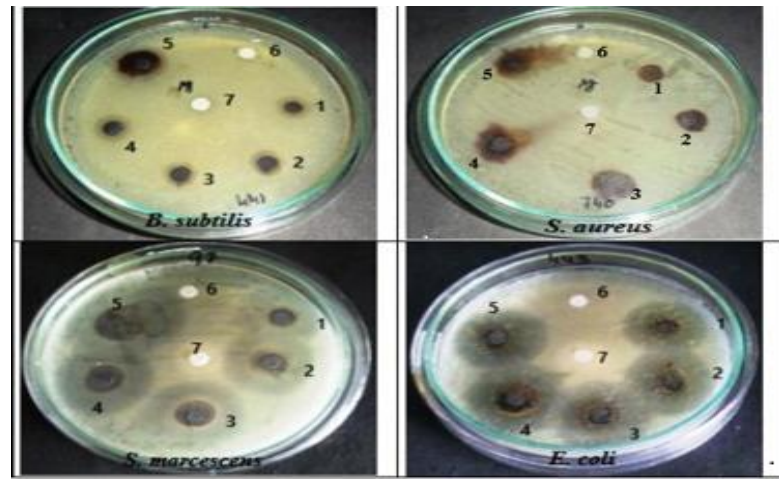

Figure 4. Action of prepared compounds on (Candida albicans)

Table 4 shows anti- bacterial and antifungal results which were interpreted in terms of the diameter of inhibition zone for antibacterial activity showed medium biological effect against Staphylococcus aureus and against E.coli, although it showed high effect forward Candida albicans.

\section{Conclusion:}

This paper reports the changes in various physical properties associated with the derivatization of sulfamethoxazole. The properties studied include by FTIR, and ${ }^{1} \mathrm{H}-\mathrm{NMR}$ spectroscopies that derivatization substantially changed the pharmaceutical properties antibacterial activities of these compounds against Gram-positive bacteria (Staphylococcus aureus,), Gram-negative bacteria (Escherichia coli,) and yeast-like fungi (Candida albicans)
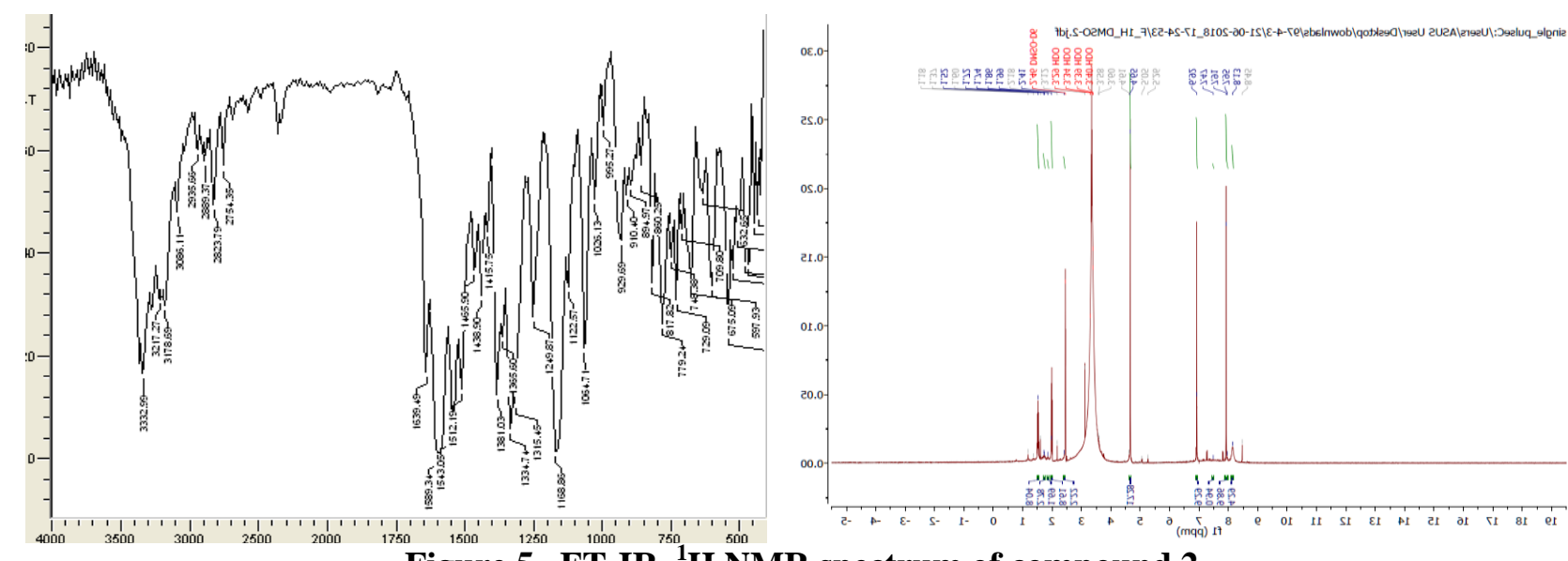

Figure 5. FT-IR ${ }^{150}$ H $\mathbf{H}$ NMR spectrum of compound 2 

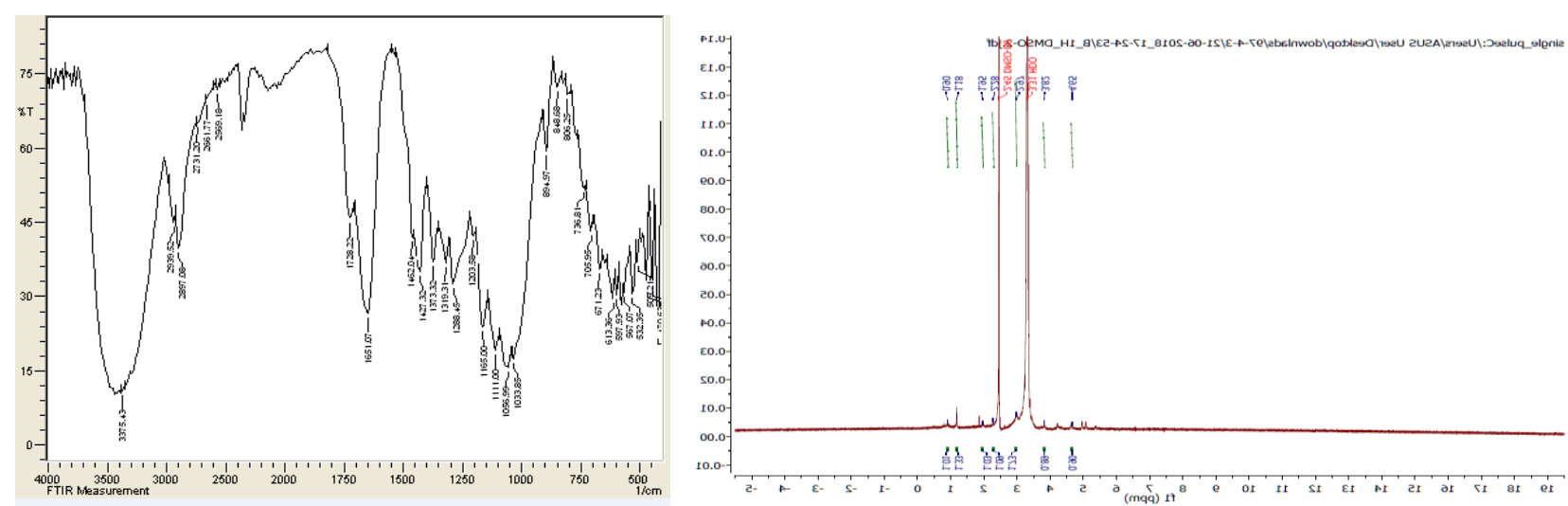

Figure 6. FT-IR , ${ }^{1} \mathrm{H}$ NMR spectrum of compound 4

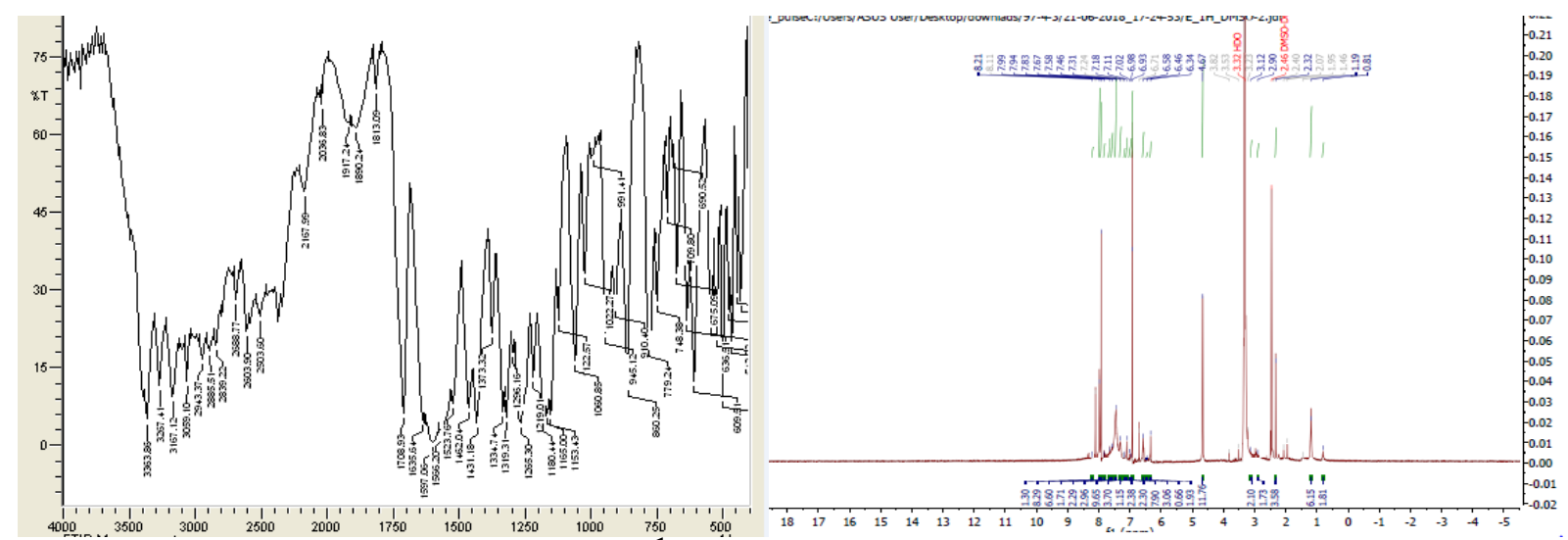

Figure 7. FT-IR, ${ }^{1} \mathrm{H}$ NMR spectrum of compound 8

\section{Author's declaration:}

- Conflicts of Interest: None.

- I hereby confirm that all the Figures and Tables in the manuscript are mine. Besides, the Figures and images, which are not mine, have been given the permission for re-publication attached with the manuscript.

- Ethical Clearance: The project was approved by the local ethical committee in University of Baghdad.

\section{References:}

1. Zhou W, Moore DE. Photosensitizing activity of the anti-bacterial drugs sulfamethoxazole and trimethoprim. J. Photochem Photobiol B. 1997 May 1;39(1):63-72.

2. Minglu M, Yiyun $C$, Zhenhua $X$. Evaluation of polyamidoamine (PAMAM) dendrimers as drug carriers of anti2bacterial drugs using sulfamethoxazole (SMZ) as a model drug. Eur J Med Chem. 2007;42(1):93-98.

3. Gupta R, Kazmi I, Afzal M, Khan R, Chauhan M, AlAbbasi FA, Ahmad A, Anwar F. Combination of sulfamethoxazole and selenium in anticancer therapy: a novel approach. Int J Mol Sci . 2013 Dec 1;384(12):279-285.

4. Jurado R, Carpenter SL, Rimland D. trimethoprimsulfamethoxazole-induced meningitis in patients with HIV infection. Am J Med Sci. 1996 Jul 1;312(1):2729.
5. Hida S, Yoshida M, Nakabayashi I, Miura NN, Adachi Y, Ohno N. Anti-fungal activity of sulfamethoxazole toward Aspergillus species. J Biol Pharm Bull 2005;28(5):773-778.

6. Brain RA, Ramirez AJ, Fulton BA, Chambliss CK, Brooks BW. Herbicidal effects of sulfamethoxazole in Lemna gibba: using p-aminobenzoic acid as a biomarker of effect. Environ Sci Technol. 2008 Oct 31;42(23):8965-8970.

7. Macingwana L, Baker B, Ngwane A, Harper C, Cotton MF, Hesseling A, Diacon AH, Van Helden P, Wiid I.(SMZ) enhances the antimycobacterial activity of rifampicin .J. Antimicrob .Chemother. 2012: 67(12)2908-2911.

8. Forgacs P, Wengenack NL, Hall L, Zimmerman SK, Silverman ML, Roberts GD. Tuberculosis and trimethoprim-sulfamethoxazole. J. Antimicrob Agents Chemother . 2009 Nov 1;53(11):4789-4793.

9. Mina S , Fereshteh G, Mohammad M, Gholamreza D, Mohammad A, Abbas S. Synthesis and biological investigation of some novel (SMZ) and aide derivatives containing coumarin moieties. Iran J. Pharm Res. 2014:13(3)881-892.

10. Ishwar B, Sunil K, Jainey $P$, Shastry C. Antimicrobial studies of synthesized azetidinone derivatives from (SMZ) moiety. J.Chem. Pharm.Res., 2011:3(3)114-118.

11. Hassan A, Mourad A, El-Shaieb K, Abou-Zied A. Synthesis of 1, 3, 4-thiadiazole, 1, 3, 4-thiadiazine, 1, 3, 6-thiadiazepane and quinoxaline derivatives from symmetrical dithiobiureas 
thioureidoethylthiourea derivatives. J. Molecules. 2005;10(7):822-832.

12. Naoto U , Hidenari S, Akihisa T, Reiko E, Shigeyuki K, Shigeru O. Design, Synthesis and Pharmacological activity of nonallergenic pyrazolone type anti-pyretic analgesics. J.Med.Chem.. $2010: 53$ (24)8727-8733.

13. Mzilikazi F, Ekemini D, Praveen K, Edikarlos M, Kamal K, Maya M, Synthesis of novel 1,2,4thiadiazinane 1,1-dioxides via three component type reaction. J. RSC Adv.2018 : 8. 37503-37507.

14. Modhavadiya VA. Synthesis, characterization, spectral studies, biocidal activities of $\mathrm{Fe}$ (II) and $\mathrm{Cu}$ (II) complexes of azo dye ligand derived from sulfamethoxazole and substituted p-cresol. Oriental J. Chem. 2012;28(2):921-925.
15. Sahoo J, Kumar Mekap S, Sudhir Kumar P. Synthesis, spectral characterization of some new 3heteroaryl azo 4-hydroxy coumarin derivatives and their antimicrobial evaluation. J Taibah Univ Med Sci . 2015 Apr 1;9(2):187-195.

16. Jialong S, Yuanming Z. Synthesis and antifungal activity of the novel pyrazole carboxamide and isoxazolol pyrazole carboxylate. Int $\mathrm{J}$ Mol Sci, 2015:20 (3):4383-4394.

17. Julia H, Wilton A R, Pedro P H, Raphael E, Alexandre C, Wilton R, Pedro P. Silver complexes with sulfathiazole and (SMZ) Synthesis, spectroscopic characterization and antibacterial assays. Polyhedron, J. Taibah Univ Med Sci. 2015:85(8): 437-444.

\section{تحضير وتثخيص ودراسه الفعاليه البايلوجيه لبعض المشتقات الجديدة لدواء سلفاميثوكسازول}

\section{سناء عبد الصاحب}

قسم الكيمياء، كلبة العلوم للبنات، جامعة بغداد، بغداد، العر اق

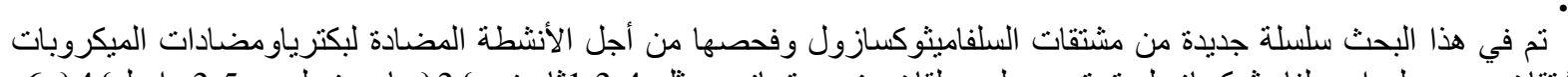

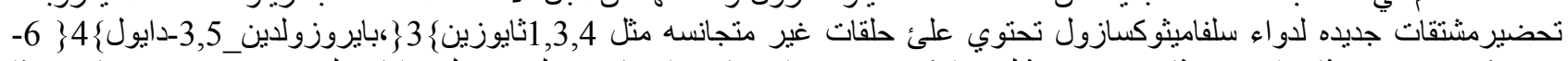

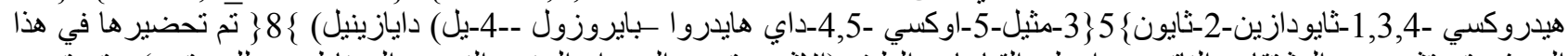

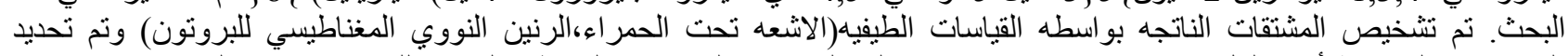

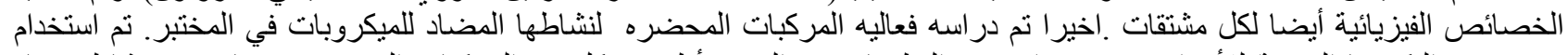

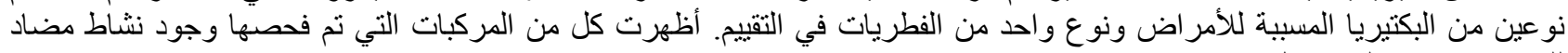
للميكروبات جيد إلى معتدل. الكلمات المفتاحية: تحضير،تشخيص، الفعاليه البيولوجيه، سلفاميثوكسازول 